Вісник Дніпропетровського університету. Серія: геологія, географія. 24 (2), 2016, 98-105.

Vìsnik Dnìpropetrovs'kogo unìversitetu. Serîa Geologîa, geographìâ

Dnipropetrovsk University Bulletin. Series: geology, geography. 24 (2), 2016, 98-105.

Doi: $10.15421 / 111637$

http://geology-dnu.dp.ua

УДК 56.012.3 (477.8)

\title{
Текстури поверхонь наверствувань в осадовій товщі неогену Передкарпатського прогину
}

\author{
${ }^{1}$ Петруняк М. Д., ${ }^{2}$ Черемісська О. М., ${ }^{3}$ Петруняк Г. М., ${ }^{2}$ Черемісський Ю. В. \\ ${ }^{1}$ Украӥнське мінералогічне товариство, Львів, Украӥна \\ ${ }^{2}$ Інститут геології та геохімї̈ горючих копалин НАНУ, Львів, Україна

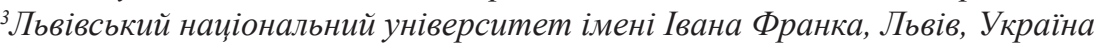

\begin{abstract}
Анотація. Детальне вивчення слідів життсдіяльності представників тваринного і рослинного світу дало змогу провести реконструкцію палеокліматичних, палеогеографічних та гідродинамічних особливостей розвитку Карпатського регіону. В результаті досліджень отримано актуальну інформацію про умови накопичення відкладів континентальних, прибережно-морських та руслових фацій в неогеновому комплексі Передкарпатського прогину. Трасовані, локально згруповані чи поодинокі відбитки біогенного та абіогенного походження в осадовій товщі приурочені до добротівської та стебницької світ аквітан-лангійського віку. Вони добре збережені та унікальні. Із застосуванням методів формаційного, літолого-фаціального, структурного, палеогеографічного, палеоекологічного та палеотектонічного аналізів проведено літолого-стратиграфічну кореляцію понад 80 повних відслонених стратиграфічних розрізів осадових порід добротівської та стебницької світ неогену в межах Самбірської підзони Передкарпатського прогину. На основі одержаних результатів виявлено закономірності знаходження та стратиграфічну прив'язку відбитків та проведено реконструкцію палеокеанографічних умов осадконагромадження в аквітан-лангійський час. Актуальність теми досліджень зумовлена можливістю використання результатів із метою надання якісної і кількісної оцінки кліматичним, палеогеографічним та гідродинамічним особливостям розвитку Карпатського регіону в неогеновий час.

Ключові слова: Передкарпатський прогин, палеоіхнологія, неоген, стебницька світа, добротівська світа, проблематичні відбитки.
\end{abstract}

\section{Textures of the layering surfaces in the Neogene sedimentary formation of the Precarpathian foredeep}

\author{
${ }^{1}$ Petrunjak M. D., ${ }^{2}$ Cheremisska O. M., ${ }^{3}$ Petrunjak G. M., ${ }^{2}$ Cheremissky Yu. V. \\ ${ }^{1}$ Ukrainian Mineralogical Society, Lviv, Ukraine \\ ${ }^{2}$ Insitute of Geology and Geochemistry of Combustible Minerals of NASU, Lviv, Ukraine \\ ${ }^{3}$ Lviv National University named after Ivan Franko, Lviv, Ukraine
}

Article is concentrated on the unique preservation of vertebrates, plants and atmospheric phenomena textures on layering surfaces of Neogene sedimentary complex of the Precarpathian foredeep. Footprints and their volumetric reflections have represented the smallest details of objects sculptures and hydrodynamic regime of sedimentation basin. For obtaining the reliable results of reserching, stratigraphic correlation and reconstruction of paleooceanographic conditions of sedimentation in Neogene sedimentary basin, the authors applied such methods: formational, lithofacies, structural, paleogeographical, paleotectonical and paleoecological. Basing on the evidence data, lithologo-stratigraphic correlation was conducted for more than 80 complete outcrops of sedimentary rocks of Dobrotiv and Stebnyk suites of Neogene within Precarpathian foredeep. Established the periodicity in sedimentation process, reconstructed the conditions of formation, saving and disposal of biogenic and abiogenically textures. Reserches are conducted on the base of a detailed study of the most complete outcrops of Dobrotiv and Stebnyk suites in the basin of the river Prut and actually rock material, selected by authors in indigenous occurrence. Dobrotiv suite in the area of perycline fold's closure of the Dobrotiv's anticline, described in several stratigraphic sections. Correlation of obtained data indicates on facial stability of the layer with reflections of footprints on reaching (30-40 m) in the range of $1620 \mathrm{~m}$, which is confined to the limit switch of Sloboda conglomerates in deposits Dobrotiv suite. The greatest accumulation of paleoihnological textures and traces of atmospheric phenomena on the surface of layers is controlled by red sandstone layer. Stebnyk suite is characterized by typical continental formation sign of redcolor layers, covered with thick layer of salt. It is represented by two lithological-facies complexes: Vyrva - clay-psammite (520-600 m) and Nadvirna - psammiteclay $(570-660 \mathrm{~m})$. During the fieldwork 2008-2016 years, the authors recorded a significant number of traces of footprints and their volumetric reflections (vertebrates, atmospheric phenomena, birds, gazelles, predators, reptiles, amphibians and other animals). Established pattern of their distribution and binding to distinct stratigraphic levels in sediments of Dobrotiv and 
Stebnyk suites. The absence of the new theoretical and practical information causes to classified a significant number of them in the category of problematic. On the surface layers of siltstone, sandstone, marl, clay recorded a numerous prints traces of vertebrates and rare texture of erosion, cracks of drying, ripples, reflections of ice crystals, relics of the root system of plants, channels selection of gas, isolated laying eggs of birds and caviar of amphibians. Survival of sculptural details of many rare traces of vertebrates is unique in Neogene sediments of Precarpathian foredeep, but in the process of preparing surfaces of the layering the authors established areas, which exposed to intense activity of organisms, atmospheric and hydrodynamic factors on the stage of sedimentogenesis.

Keywords: Precarpathian foredeep, paleoichnology, Neogene, Stebnik suite, Dobrotiv suite, problematic footprints.

Вступ. Унікальні відбитки слідів хребетних та різноманітних атмогліфів у верствах неогенових відкладів Передкарпатського прогину знаходять у вигляді трасованих, локально згрупованих або поодиноких слідів на поверхнях шаруватості осадових порід. Сліди та їх контрвідбитки відображають найменші деталі скульптури об'єктів, а також наслідки впливу на них гідродинамічного режиму, що панував у басейні седиментації.

У результаті спеціальних досліджень геологічних об'єктів у басейні р. Прут та її правих приток у 2008-2016 роках, автори одержали нові дані, на основі яких зроблено висновки щодо умов формування неогенового породного комплексу Передкарпаття.

Стан вивченості. Наукові повідомлення про одиничні знахідки відбитків слідів хребетних протягом тривалого часу залишались поза увагою дослідників. Перша грунтовна праця О. С. Вялова [Vjalov, 1966] містила правила опису, розроблення принципів номенклатури та проведення систематизації (класифікації) слідів життєдіяльності організмів. Згодом, Т. А. Денисова [Denisova, 1970] встановила закономірності розподілу та збереження біогенних текстур в осадових відкладах Передкарпаття, тоді як у подальших працях подібна інформація подається лише у вигляді стислої констатації самого факту знахідки.

Матеріал і методи досліджень. 3 метою встановлення палеогеографічних закономірностей, а також реконструкції палеотектонічних та палеоокеанографічних умов проведено низку детальних польових обстежень унікальних місцезнаходжень палеоіхнологічних відбитків у відкладах аквітан-лангійського віку Передкарпатського прогину. В ділянці периклінального замикання Добротівської антикліналі по потоку Ослава (права притока р. Прут) в інтервалі 1620 м задокументовано ряд стратиграфічних перетинів, що містять у значній кількості відбитки слідів хребетних у відкладах добротівської світи (рис. 1).

У загальних рисах відбитки слідів хребетних достатньою збережені, однак їх діагностика ускладнюється проблематикою питань способу життєдіяльності тварин, значними механічними змінами зцементованих відкладів, а також впливом інших факторів седиментогенезу, котрі безпосередньо впливають на зовнішній вигляд відбитків. Це стосується інших відбитків, діагностика яких залишається тільки припущенням (рис. 2).

Кореляція отриманих даних свідчить про фаціальну витриманість горизонту 3 відбитками
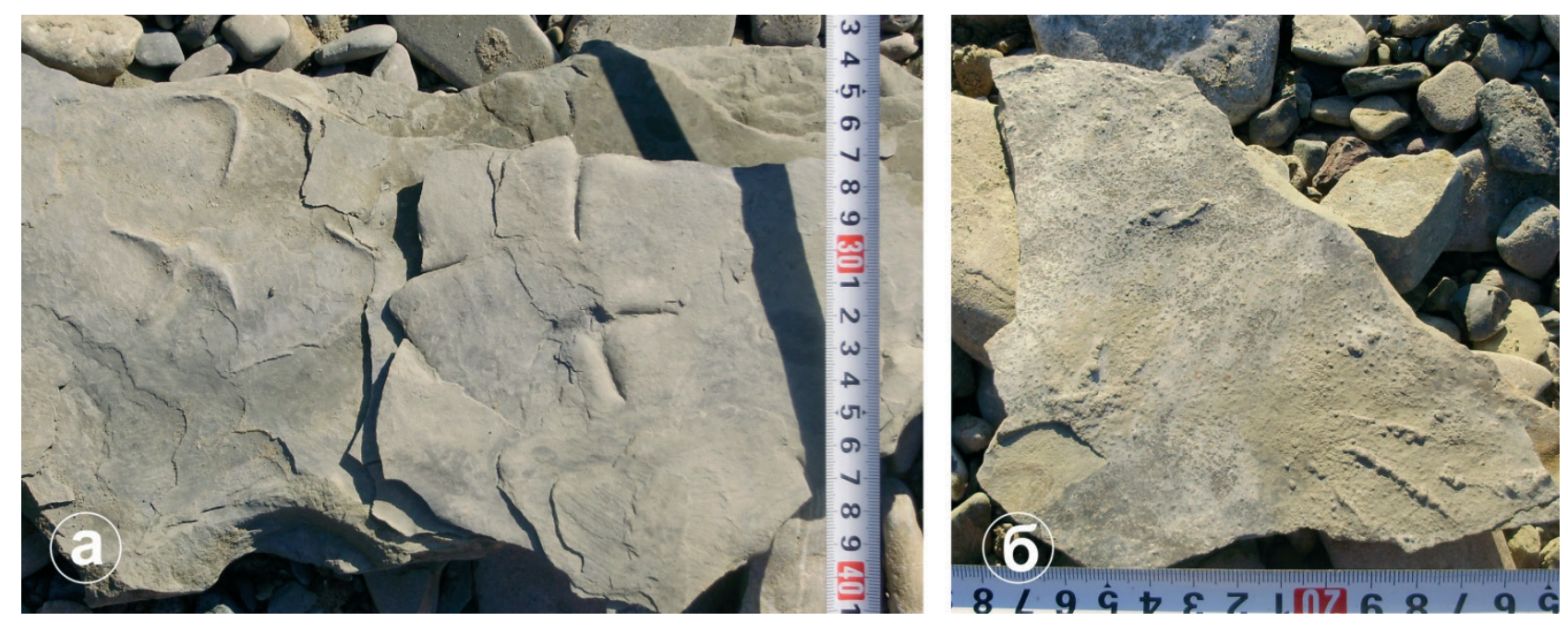

Рис. 1. Відбитки слідів хребетних у відкладах добротівської світи (потік Ослава, притока р. Прут): $a$-прямі та зворотні відбитки слідів чайки на розшарованій поверхні мергелистого алевроліту, $\sigma$ - відбитки слідів земноводного 

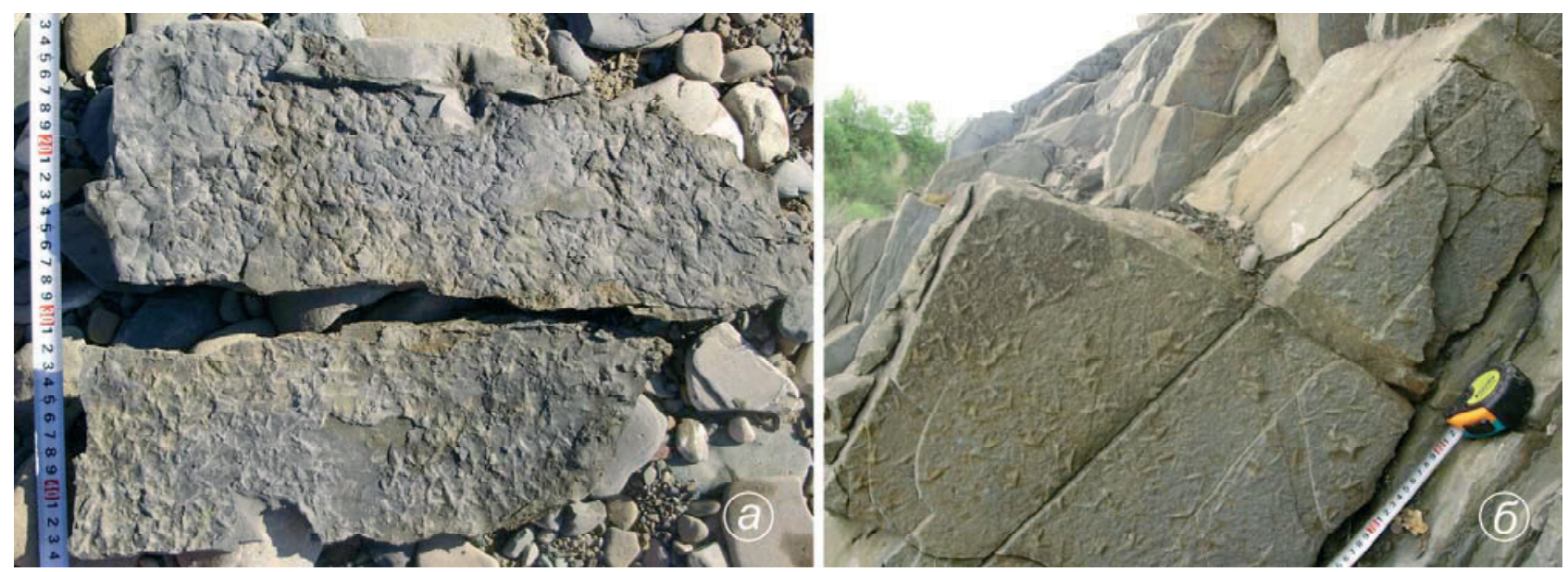

Рис. 2. Відбитки та контрвідбитки слідів птахів:

$a$ - препарована поверхня алевроліту добротівської світи, гирло потоку Ослава (права притока

р. Прут),

б - підошва масивного пісковику стебницької світи (смт Ланчин, р. Прут)

по простяганню (30-40 м) та його стратиграфічну приуроченість до межі переходу слобідських конгломератів у відклади добротівської світи. При цьому найбільший розвиток палеоіхнологічних відбитків та атмогліфів у відкладах контролюється верствою червоноколірного пісковику, особливого значення якому надає Т.А. Денисова [Denisova, 1970]. Залягання порід наближене до горизонтального і сприятливе для ступінчатого пошарового препарування, а на поверхнях нашарування спостерігаються численні відбитки слідів Avipeda filiportatis Vialov, Bestiopeda bestia Vialov, Pecoriptda gazelle Vialov, Pecoripeda satyri Vialov та багатьох інших.

На поверхнях нашарування алевролітів, пісковиків, мергелів, глин виявлено сліди розмиву,

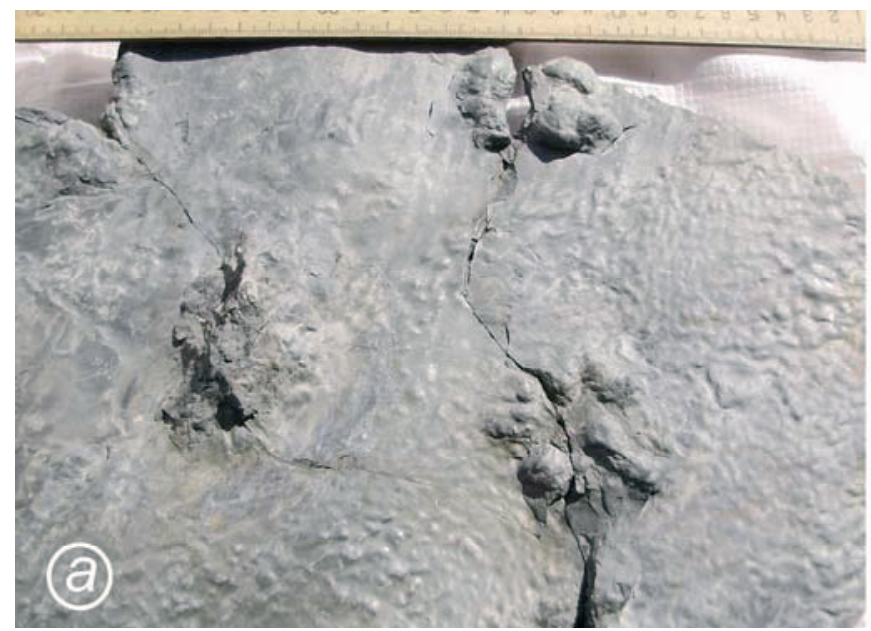

тріщини всихання, брижі, відбитки кристалів льоду, наслідки життєдіяльності хребетних і безхребетних. Часто на підстильних і перекривальних поверхнях проверстків, трапляються чіткі, добре збережені відбитки слідів хижаків і птахів (рис. 3), які зберігають деталі їх первісної морфологічної будови [Petrunjak, 2012; Petrunjak, 2012;].

Окремої уваги заслуговують відбитки слідів птаха і хижака в шарах Гука, які виявлені [Tkachenko, 1967] під час проведення стратиграфічної кореляції цих верств із добротівською світою. Однак, якщо верстви Гука співставити 3 кросненськими відкладами, в яких установлено лише один відбиток сліду птаха, то нижню вікову межу палеоіхнологічних відбитків в Карпатах можна значно опустити.

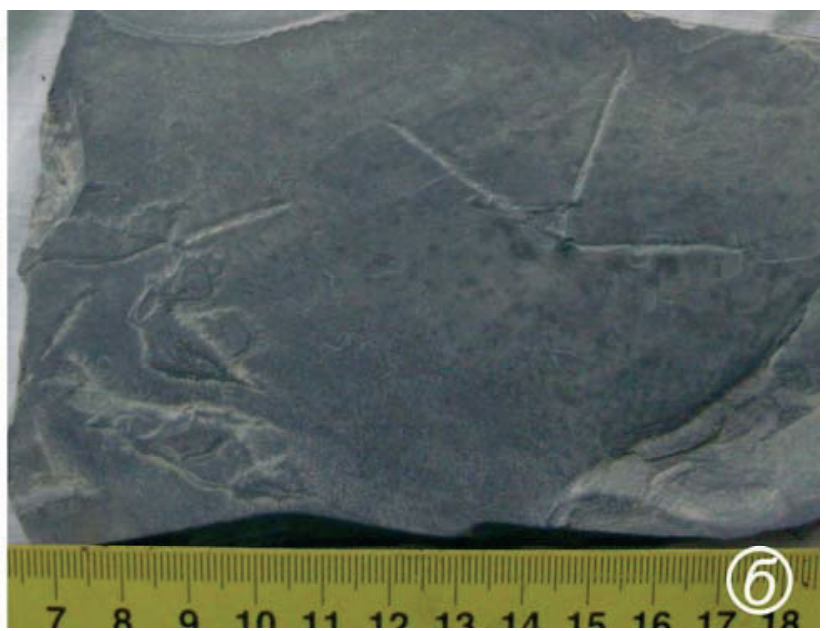

Рис. 3. Поверхні проверстків порід добротівської світи з добре збереженими відбитками слідів хижаків та птахів:

$a$ - контрвідбитки слідів лисиці на підошві алевроліту, $\sigma$ - сліди птаха на покрівлі алевроліту 
Автори детально обстежили шари Гука в перекиненому заляганні на західній околиці м. Косів по р. Рибниця. Тут корінні виходи відзначаються доброю відслоненістю, в загальному представлені гладкими поверхнями нашарування 3 локально розвиненими зморшкуватими ієрогліфами, слідами волочіння, брижами. Підошва верстви суцільно вкрита брижами та двома прямолінійними трасами $з$ шістьма слідами невизначеного виду птаха та сімнадцятьма проблематичними відбитками невстановленого походження (рис. 4). Палеогра- фічна реконструкція показує, що переміщення об'єкта відбувалося по азимуту $110^{\circ}$ уздовж берега в хвилеприбійній зоні плитководного басейну.

Площина 3 трасою проблематичних слідів простежується у відслоненому інтервалі від 0 до 8,78 м. Перші відслонені 4,60 м являють собою підошву алевроліту 3 лінійною трасою негативних відливів слідів у вигляді невисоких виступів, збагачених акцесорними мінералами. Продовження траси в корінному заляганні в інтервалі 4,60-8,00 м природно відвалене, а збережений лише іï фраг-

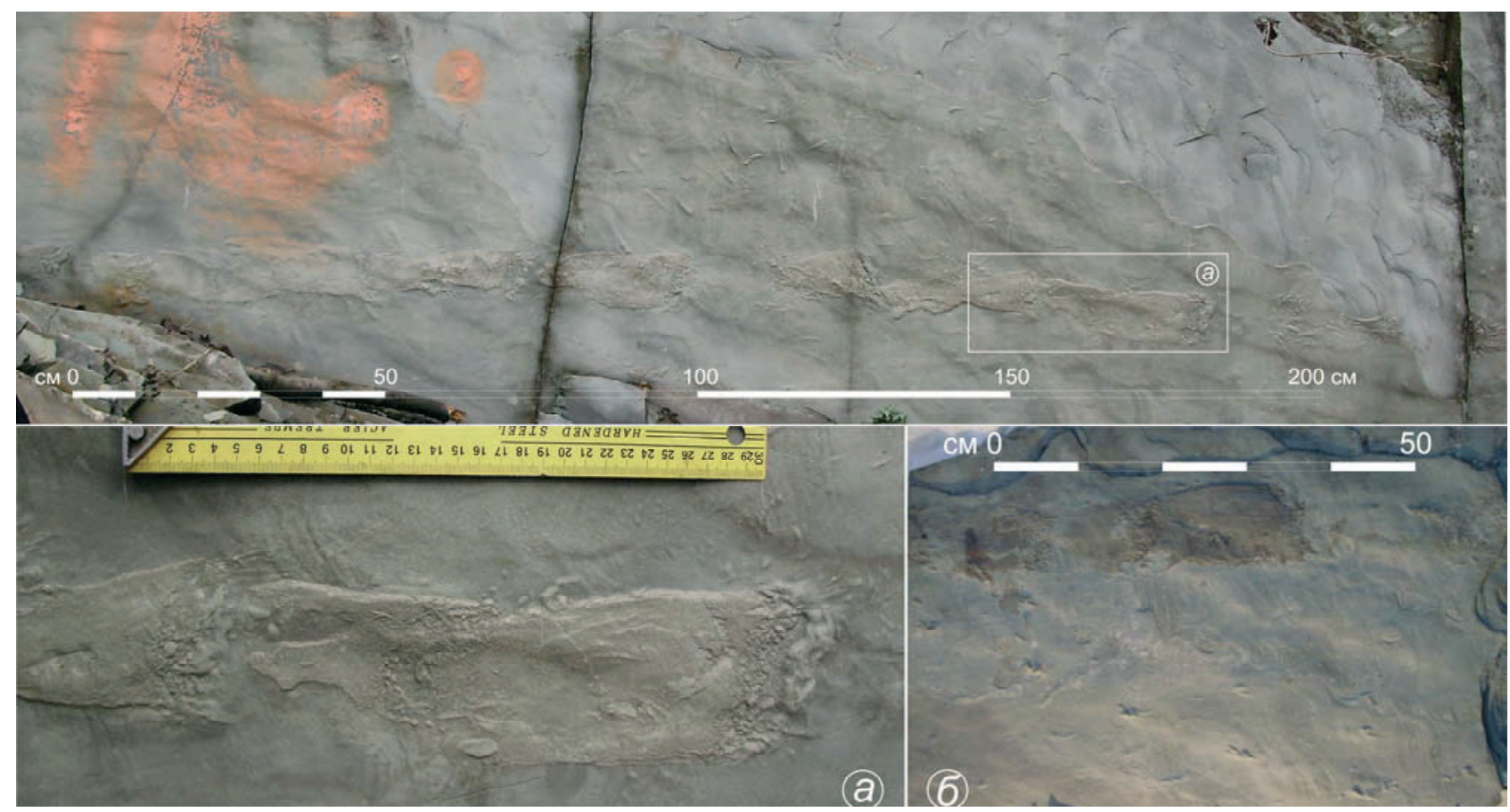

Рис. 4. Корінні виходи шарів Гука - підошва алевроліту з хвилеприбійними знаками та проблематичними відбитками (р. Рибниця, м. Косів):

$a$ - фрагмент траси слідів невстановленого походження, $\sigma$ - траса слідів птаха та проблематичний відбиток на підошві алевроліту, вилученого з корінного залягання в інтервалі 8,0-8,78 м)

мент у вигляді контрвідбитка на покрівлі підстелювального алевроліту, відібраного в інтервалі 8,00-8,78 м. Далі відслонення закінчується обривом над руслом ріки.

Стебницька світа. Відбитки слідів тварин у відкладах стебницької світи, встановлені попередніми дослідниками, спостерігались лише поблизу стратиграфічної межі з добротівськими відкладами, які залягають нижче. Нові дані дозволяють стверджувати про значний розвиток верств і проверстків із відбитками біогенного походження в строкатоколірній частині розрізу вирвинського глинисто-псамітового (520-600 м) та надвірнянського псаміто-глинистого (570-660 м) фаціальних комплексів стебницької світи. Під час геохімічних та мінералогічних досліджень [Petrunjak, 1977] у відкладах стебницької світи виявлено відбитки слідів птахів, газелей, хижаків, плазунів, земноводних та інших тварин, приурочених до чітких стратиграфічних рівнів.

Зазвичай, верстви 3 відбитками характеризуються за текстурними ознаками (косошаруватість, ерозійні врізи, внутрішньоформаційні перемиви, брижі, сліди течій, стікання води, відбитки дощових крапель і кристалів льоду, рідкісні кладки яєць пернатих та ікри земноводних, релікти кореневої системи рослин, тріщини всихання, канали газовиділень тощо) та часто розташовані в безпосередній близькості або збігаються 3 поверхнями проверстків та пластів із мідною мінералізацією. 
Найбільшу кількість відбитків слідів хребетних зафіксовано в басейні р. Прут на відслонених розрізах стебницьких відкладів. Перший стратиграфічний рівень приурочений до нижньої частини світи (поблизу смт Делятин), де вона складена тонкими проверстками строкатих глин і алевролітів. У цих відкладах виявлено проверсток пісковику сірого, дрібнозернистого, карбонатного, сильно слюдистого біля підошви із включеннями дрібних уламків (3-5 мм) глин, схожих на підстильні відклади. Пісковик косошаруватий (15-20 см), його нижня поверхня нерівна і в деталях ілюструє специфіку поверхні підстильних відкладів. На ній зафіксовано тонкі відливи сітки тріщин усихання, сліди розмивання давніших відкладів, порушення донного осадку від переміщення птахів. Тут же встановлено шість відбитків слідів птахів одного і того ж виду, визначення якого викликає певні труднощі, оскільки порівняння з літературними даними свідчить про повну відсутність аналогій з раніше описаними. Однак співвідношення і характер відбитків слідів дозволяє стверджувати, що процес їх захоронення відбувався відносно швидко.

Другий стратиграфічний підрівень розташований в цьому ж місці. Вміщувальні породи схожі на вищезгадані, містять проверсток пісковику зеленувато-сірого, поліміктового, слюдистого, карбонатного з розмаїттям акцесорних мінералів у підошві, а також із включенням дрібної гальки підстильних відкладів. На його підошві простежуються сліди течії північно-східного напряму (азимут 60-70 $)$ з трьома крупними відбитками птаха, схожого з Avipeda filiportatis Vyalov.

Третій підрівень виділений в районі смт Яблунів по р. Лючка, де серед тонкошаруватої мергелисто-вапнякової пачки на гладкій нижній поверхні проверстка виявлено три барельєфи слідів диких кіз і відбитки крапель дощу.

Обстеження розрізів осадової товщі стебницької світи по ріках Бистриця Надвірнянська, Прут, Лючка, Чечва, Бистриця Підбузька показали, що в інтервалах між зазначеними вище стратиграфічними рівнями поряд із тріщинами всихання, відбитками дощових крапель, наслідків конседиментаційних розмивів міститься значна кількість відбитків слідів тварин. Очевидно, процес нагромадження відкладів відбувався в умовах озерно-алювіальних рівнин [Cheremisskaja, 2013; Cheremiss'ka, 2012].

За час польових досліджень 2008-2016 pp., автори зафіксували значну кількість прямих слідів хребетних та їх барельєфних відливів, атмогліфів, ієрогліфів у стебницьких відкладах. Відсутність нової теоретичної та прикладної інформації змушує відносити їх до розряду проблематичних. На окремих відкритих площинах нашарування слідів хижаків спостерігаються на покрівлі пісковику, де вони мають добре збережені тріщини всихання (рис. 5), а їх підошва переважно збагачена акцесорними мінералами з відбитками слідів невизначеного птаха (рис. 5). У стебницькій світі, крім дрібного вугільного детриту і вітринітизованих рослинних решток [Petrunjak, 2014] після катастрофічної повені 2008 року знайдено відбиток водорості, наповненої псамітовим теригенним матеріалом (рис. 5).

Збереженість скульптурних елементів слідів хребетних у відкладах стебницької світи виняткова. На окремих стратиграфічних рівнях унікальні відбитки слідів тварин фіксуються по нашаруванню у проверстках глин, однак через фізичні властивості цих порід препаруванню такі взірці практично не підлягають.

Обговорення результатів. Текстури біогенного походження відомі $з$ девону, однак відбитки слідів хребетних у молодших відкладах відносять до рідкісних палеонтологічних решток, оскільки ix збереження потребує особливих умов фосилізації [Vjalov, 1966]. Зокрема, Чарльз Дарвін у свій час вказував на важливість виявлення аналогічних відбитків слідів хребетних за постійної відсутності їх скелетних решток в осадових породах [Vjalov, 1966].

Ретельне обстеження відкладів, особливо в місцях значного розвитку відбитків слідів, показує закономірність у незбереженості скелетних решток у відкладах аквітан-лагнійського віку. Це підтверджується одиничним зафіксованим фактом знаходження алевроліту зі збереженим відбитком хребта, плавників і міхурів риби (рис. 6).

Вдаючись до принципу актуалізму, одержуємо нагоду проводити екстраполяцію між сучасними спостереженнями і ситуаційними обставинами минулого. Під час польових робіт по р. Прут часто зустрічаються згруповані на мілинах сліди єдиної чаплі в околиці (рис. 7), які перебували в несприятливих для збереження умовах та під час чергового дощового періоду були розмиті.

3 іншого боку, викопні сліди диких кішок, кіз, птахів вражають ідентичністю з сучасними видами. Наприклад, у Карпатській споруді інше місцезнаходження викопних слідів відоме в Румунії у горах Вранчей, де знайдено сліди мастодонтів, верблюдів тощо. Румунські геологи, порівнюю- 

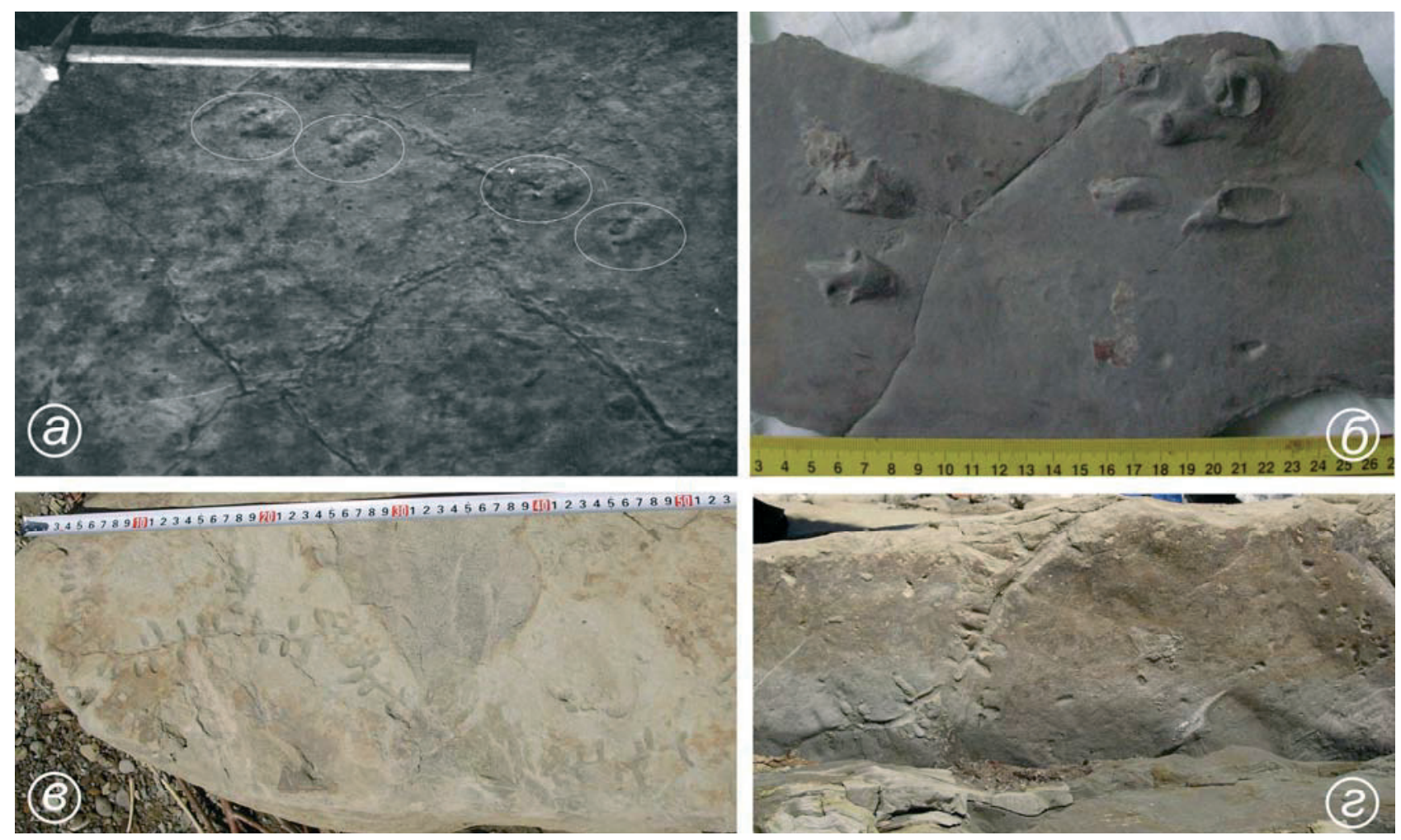

Рис. 5. Біогенні та абіогенні текстури у відкладах стебницької світи в долині р. Прут:

$a-$ полігональні тріщини всихання та сліди хижака з сімейства кошачих на покрівлі пісковику;

$\sigma$ - сліди невизначеного птаха на покрівлі алевроліту;

в - відбиток водорості на покрівлі верстви пісковику, який зафіксовано у відвалах;

2 - контрвідбиток водорості в підошві пісковику (корінне залягання) з вертикальними ходами мулоїдів

чи викопні сліди із сучасними встановили близьку схожість впритул до сучасних родів і видів [Denisova, 1970]. Під час аналогічного співставлення слідів газелей, установлених на Прикарпатті, також не виявлено найменших змін у розмірі і формі копит [Vjalov, 1966]. В цьому відношенні справедливе зауваження М. Малкея [Malkej, 1983] про те, що Чарльз Дарвін у своїх працях, очевидно, ототожнює еквівалентність природного і штучного відбору.

Зауважимо, що відклади стебницької і частково добротівської світ є утворами червоноколірних формацій мобільних зон із переважаючими аридними умовами літогенезу.

Формування строкатоколірних відкладів стебницької світи в Передкарпатському прогині пов'язане $з$ областями живлення на північному заході і південному сході, які являли собою підняття 3 покривами червоних і бурих глин. Проміжок між ними являв собою міжгірську рівнину. Первинний матеріал, який надходив із області осадконагромадження, був червоноколірним і утворювався в корах вивітрювання латеритного типу.
Переважає думка, що басейн стебницького часу являв собою лагуну, яка періодично з'єднувалась на південному сході і на північному заході з відкритим морем. Однак дані замірів косої шаруватості, слідів течій, напрямків оповзання осадів, атмогліфів, палеоіхнологічних відбитків, розподіл крупноуламкового і вулканогенного матеріалу свідчить про інші умови осадконагромадження.

У ранньостебницький час на північному заході існувало крупне підняття 3 різкоамплітудним рельєфом та густою гідросіткою. Складене воно було метаморфічним комплексом, юрськими вапняками i, частково, відкладами флішу. За впливу засушливих і дощових періодів, що часто чергувалися, підняття до початку пізньостебницького часу пенепленізувалось. Область осадконагромадження в південно-східному напрямку являла собою передгірську рівнину, в якій нагромаджувались річкові алювіальні товщі. Інтенсивне вивітрювання в області підняття мало латеритний характер, що і зумовило первинний червоноколірний характер порід. Напрямок течій протягом усього періоду був стабільним i, в основному, 


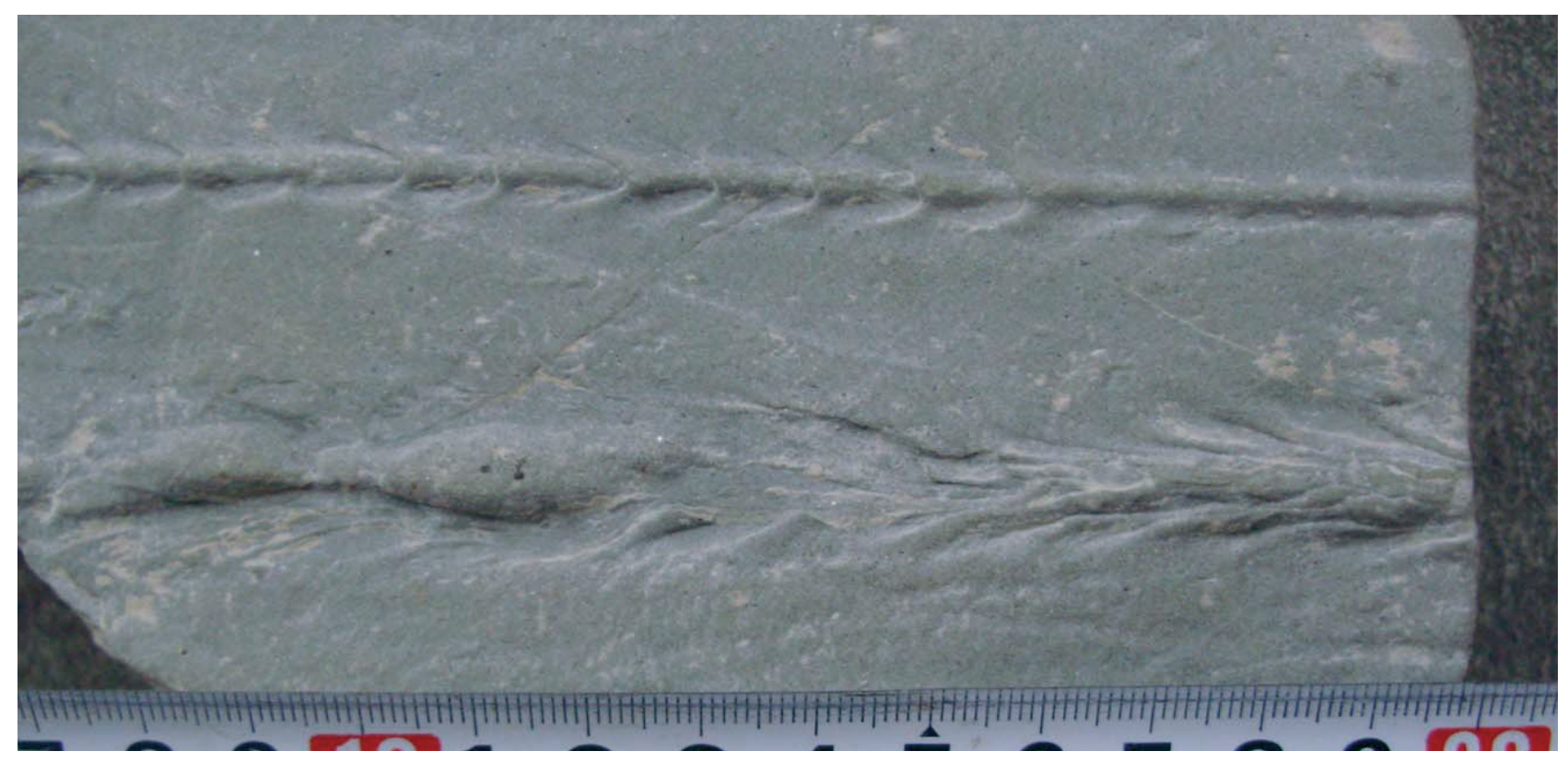

Рис. 6. Відбиток скелета риби на поверхні алевроліту стебницької світи (потік Лойовий, с. Лойова)

відповідав напрямкам, що вкладаються в сектор від $225^{\circ}$ до $250^{\circ}$. У досліджених розрізах помітного напрямку зносу матеріалу з північно-східного обрамлення платформи чи протилежного з боку Карпат не виявлено.

У південно-східній частині стебницького басейну седиментації існувала передгірська рівнина 3 рівнинним рельєфом. Область живлення була значно віддалена і являла собою злегка горбисту поверхню. На шляху транспортування уламковий матеріал зазнавав повної дезінтеграції, що супровожувалось вивільненням акцесорних та рудних мінералів. Умови в області живлення та осадконагромадження відповідали вищезазначеним, кліматичні умови були явно аридними. 3 настанням дощових періодів передгірські долини (область осадконагромадження) тимчасово затоплювалися. По численних палеоруслах формувались потужні верстви пісковиків з текстурними ознаками руслових фацій.

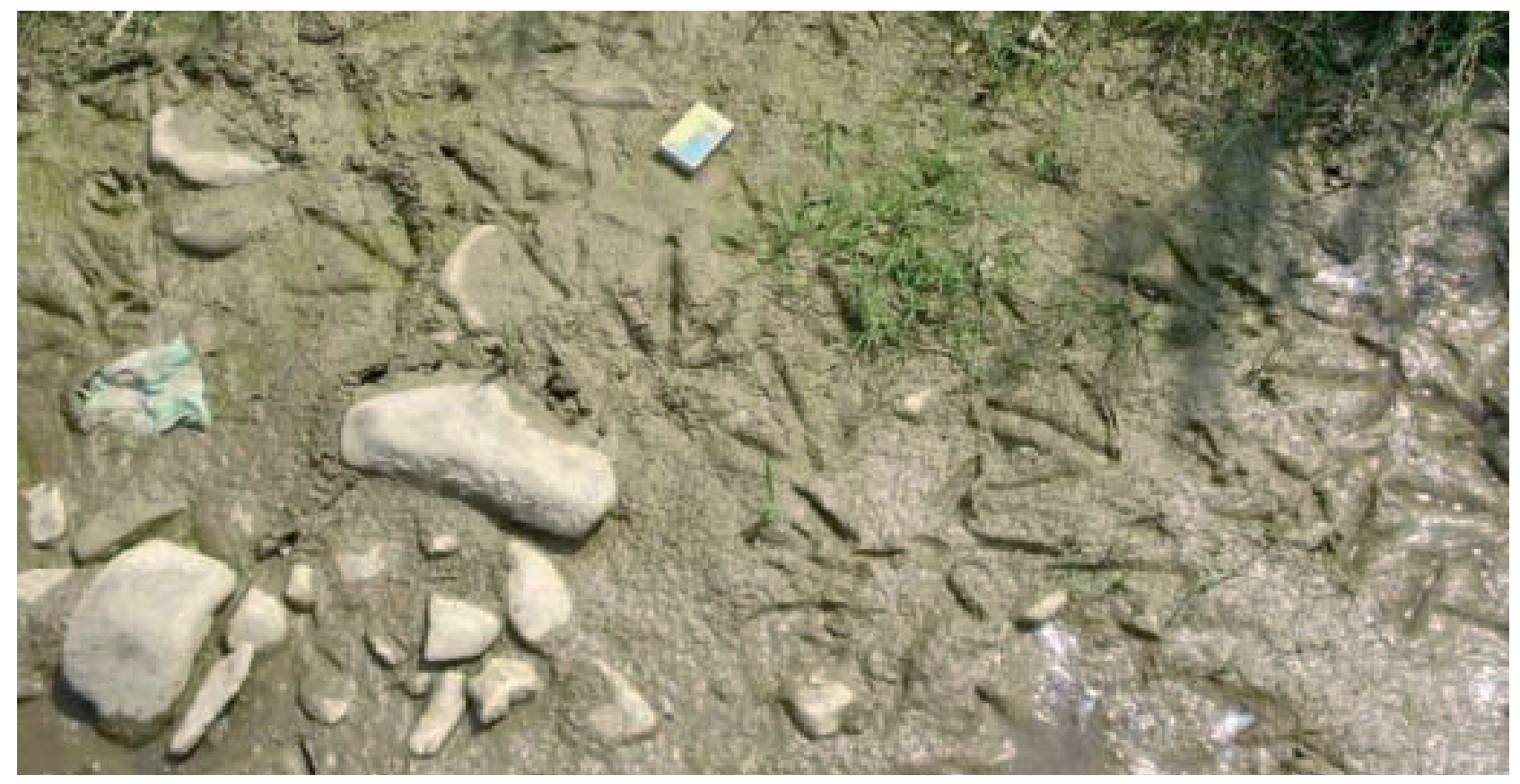

Рис. 7. Сучасні сліди чаплі на поверхні мулистого алювію р. Прут (с. Саджавка) 
В області осадконагромадження по всьому прогину росла бідна рослинність (трав'яниста, очеретяна, рідше деревовидна). Чергування засушливих та дощових періодів спричинювало часті площинні змиви відкладеного шару та перекриття його новим зі збереженням поверхні численних полігональних тріщин усихання. Часто в басейні седиментації утворювалися ділянки із застійними водами та болотною рослинністю, а періодична зміна атмосферного режиму сприяла захороненню відбитків слідів тварин. Такі знахідки в різних частинах прогину і на всіх стратиграфічних рівнях свідчать не так про бурхливий розвиток життя, як про конкретні умови формування відкладів.

Висновки. Палеоіхнологічні відбитки в Передкарпатському прогині приурочені до осадової товщі неогену і цікаві не лише винятковою збереженістю, а й різноманітністю видової приналежності.

У стратиграфічному розрізі від межі переходу слобідських конгломератів у відклади добротівської світи вирізняється пачка порід $(20-40$ м) зі значною кількістю слідів тварин, а в типово континентальних стебницьких відкладах, відбитки закономірно виявляються по всьому розрізу в інтервалі від 0 до 700 м від основи світи і до покладів солі.

Слід зазначити, що умови залягання цих відкладів тектонічно ускладнені, і лише на ділянці периклінального замикання Добротівської антикліналі (р. Прут) залягання порід наближене до горизонтального. Саме такі умови можна вважати сприятливими для пошарового препарування виняткових екземплярів із метою реконструкції палеоекологічних подій на території сучасного Передкарпатського прогину.

\section{Бібліографічні посилання}

Cheremisskaja, O. M., Cheremisskij, Ju. V., 2013. Geologo-strukturnye, litologicheskie i paleogeograficheskie aspekty formirovanija otlozhenij stebnikskoj svity Predkarpatskogo progiba [Geological and structural, lithologic and paleogeographic aspects of the formation of Stebnyk suite deposits in Precarpathian foredeep]. Materialy VII Vserossijskogo litologicheskogo soveshhanija. Novosibirsk, INGG SO RAN, pp 251-254 (in Russian).

Cheremiss'ka, O. M., 2012. Geologo-paleookeanografichni aspekty formuvannja vidkladiv stebnyc'koi' svity Karpats'kogo segmentu Paratetisu [Geological-paleooceanografic aspects of the formation of the deposits of the Stebnik's suite of the Carpathian segment of the Paratethys]. Zbirnyk materialiv mizhnarodnoi' naukovoi' konferencii'. K., p. 112 (in Ukrainian).

Denisova, T. A., 1970. Teksturnye osobennosti porod i uslovija obrazovanija dobrotovskoj svity nizhnego miocena Predkarpat'ja [Textural features of rocks and formation conditions Dobrotov suite of Lower Miocene of Precarpathians foredeep]. Izd. Nauka, 136 p. (in Russian).

Malkej, M, 1983. Nauka i sociologija znanij [Science and Sociology of knowledge]. M., Progress, 253 p. (in Russian).

Petrunjak, M. D., 1977. Prostranstvennaja lokalizacija medistyh peschanikov v Prikarpat'e [Space localization of the copper sandstones in the Precarpathian]. Mineralogija osadochnyh obrazovanij, 4. K.: Nauk. Dumka, pp. 32-35 (in Russian).

Petrunjak, M. D., Cheremiss'ka, O. M., Cheremiss'kyj, Ju. V., 2012. Dynamichnyj vplyv zhyvyh organizmiv na sedymentogenni utvorennja ta geohimichne seredovyshhe mineraloutvorennja [Dynamic effect of the living organizmes for the sedimentology formation and geochemical situation of the mineral genesis]. Zbirnyk materialiv mizhnarodnoi' naukovoi' konferencii'. K., p. 74 (in Ukrainian)

Petrunjak, M. D., Cheremiss'ka, O. M., Cheremiss'kyj, Ju. V., 2012. Mehanichnyj vplyv zhyvyh organizmiv na sedymentogenni utvorennja ta geohimichne seredovyshhe mineraloutvorennja [Mechanic effect of the living organizmes for the sedimentology formation and geochemical situation of the mineral genesis]. Zb. naukovyh prac' IGN NAN Ukrai'ny, 5, pp. 145-148 (in Ukrainian).

Petrunjak, G. M., Cheremisskaja, O. M., 2014. Organicheskoe veshhestvo kontinental'nyh geogeneracij [Organic matter of continental geogenerations]. Kadastr nedvizhimosti i monitoring prirodnyh resursov. Tula, TulGU, pp. 82-83 (in Russian).

Tkachenko, O. F, Pishvanova, L. S., Shvareva, N. Ja., 1967. Nahodka sledov ptic i hishhnika v slojah «Guka» na r. Rybnice v Predkarpat'e [Finding traces of birds and predator in the layers of "Hook" on r. Rybnitsa in Carpathians]. Bjull. MOIP, XLII(4), pp. 125-128 (in Russian).

Vjalov, O. S., 1966. Sledy zhiznedejatel'nosti organizmov $\mathrm{i}$ ih paleontologicheskoe znachenie [Traces activity of organisms and their paleontological value]. K.: Naukova dumka, 219 p. (in Russian).

Надійшла до редколегії 25.10.2016 